\title{
Modeling and managing flash flood Hazards in the State of Kuwait.
}

\author{
Ahmed Hassan $^{1,2^{*}}$ (D), Jasem A Albanai ${ }^{3}$, Andrew Goudie ${ }^{4}$
}

${ }^{1}$ Matrouh University, Egypt.

${ }^{2}$ Ministry of Education, Kuwait. *Correspondence to: ameh812000@gmail.com

${ }^{3}$ Marine Monitoring Section, Water Quality Department, Environmental Public Authority, Kuwait. Albanay.com@gmail.com

${ }^{4}$ University of Oxford, South Parks Road, Oxford, OX1 3QY, United Kingdom. andrew.goudie@stx.ox.ac.uk

\begin{abstract}
Flash flooding is one of the most devastating natural events that leads to enormous and recurring loss of life. Kuwait was subjected to severe rainstorms in the winter of 2018 and 2020 followed by an extreme violent flood that had not been known in Kuwait since 1976. It resulted in several geomorphological and environmental impacts in urban and desert areas. This produced some positive results, such as geomorphological activity in landforms, the flow of some valleys and the prosperity of wildlife in the Kuwaiti desert. Negative results included some problems in the metropolitan area and destruction of some road networks that intersect the main valleys, and which were not equipped with crossings for avoiding floods. There was also the emergence of some problems in the infrastructure. Study of flash floods requires the involvement of all scientific and executive bodies to avoid environmental risk. The study aims to: 1- Monitor geomorphological and environmental changes. 2- Assess the impact of floods in the urban areas and on infrastructure. 3- Modeling the impact. 4- Creating solutions and adaptions to the flash flood. The study uses several methods such as remote sensing (RS), geographic information systems (GIS), hydrologic modeling and fieldwork to evaluate the impact of flash flood hazards on the sustainable urban development of Kuwait state. This approach is rarely used in Kuwait. We propose a novel method that could help decision-makers and planners in determining inundated flood zones before planning future urban developments in
\end{abstract}


Kuwait, and help them to manage flood water, by identifying the most appropriate places for storage to exploit water in agriculture and drinking.

KEYWORDS: Flash floods; Hydro-Geomorphology; Rainstorms management; GIS; RS.

\section{INTRODUCTION}

Climate change research has revealed that the frequency of extreme weather phenomena with increasing damage to human assets has been gradually growing worldwide (IPCC, 2007; Kanchan and Rajiv, 2020). Flash floods are one of the worst weather-related natural disasters. They are dangerous because they are sudden and are highly unpredictable, following brief spells of heavy rain (Youssef et al., 2011; Youssef and Hegab, 2019). Flooding in urban areas occurs when the sewage and drainage systems are not capable of absorbing high-intensity rainfall. During the heavy rainfall events, the water collects and gathers speed before coming together in areas with steep slopes. As a result, the water has the power to carry away debris, rocks, trees, cars, and structures and cause serious vulnerability (Elkhrachy et al., 2021). Many studies have indicated that flash floods in arid areas, caused by storms of high intensity and short duration, are one of the most frequent, widespread, and disastrous natural hazards in Kuwait. They cause considerable damage to roads, human activities, and subsequently lead to a slump in the economy (Misak et al., 2012; KISR, 2000; Youssef and Hegab, 2019; Al-Rukaibi et al., 2017; Dawod et al., 2012). In the literature, various researchers have applied remote sensing (RS) and geographic information system (GIS) techniques to estimate flood hazard impacts on urban areas, infrastructures, agricultural areas and regarding land use changes (Mason et al., 2009; Abdelkarim et al., 2019). Others have studied flood hazard susceptibility mapping using RS data and GIS techniques with the help of statistical, probabilistic, hydrologic, and stochastic neural networks and fuzzy logic (Youssef et al., 2011; Ahmad and Simonovic, 2011). A recent papers (Essel, 2017; Portugués-Mollá et al., 2016) indicated that hydrologic assessment using 
geospatial techniques could be conducted to identify different hydrologic components, prepare hydrologic designs, and develop possible scenarios to overcome the hazards from flash flooding.

Floods in Kuwait occur during heavy rainstorms with rainfall amounting to $30-40 \mathrm{~mm}$ in one storm lasting 4-6 hours. Parts of Kuwait were subjected to flash floods during December 1934, November 1954, 2nd February 1993 (40 mm within 6-8 hours), 11th November 1997 (105 mm within 4-6 hours), January 2004, January 2007, April 2008, December 2009, November 2013, January 2014, and November 2018. They caused intensive damage to physical infrastructures such as roads, fences, water wells, oil facilities and others (Misak, 2015; KMD, 2020). RS methods in flash flood detection have been developed since the 1980s (Lowrey et al., 1981). RS is one of the most important tools in monitoring flash floods due (i) to the wide geographical areas covered by the satellite's images, (ii) the low cost of monitoring compared to traditional methods (Parcharidis et al., 2001) (especially with the availability of many satellite data for free), (iii) the presence of a huge number of different sensors installed onboard satellites, and (iv) the ability to monitor changes by comparing images before and after a specific phenomenon. RS sensors are divided into passive and active. Passive sensors give the possibility to monitor Earth's surface in true colours and a range of spectra from early blue to thermal bands. As for the active sensors, they are distinguished by their ability to monitor Earth's surface at night and day and in difficult weather conditions (Wang et al., 1995; Parcharidis et al., 2004; Saynal and LU, 2004) due to the nature of the microwaves. This makes it an effective tool in flash flood monitoring during bad weather conditions (often when a flash flood is taking place), and during subsequent water drought periods. Such conditions impede monitoring using passive RS and enhances the ability of the active sensors (Townsend, 2002). The difference between flooded and dry surfaces is determined by the difference in the radioactive behaviour reflected or emitted from the water and land surfaces. The US Geological Survey provides important data on the Landsat 8 
(passive) satellite, while the European Space Agency (ESA) provides important data for the Sentinel1 (active) satellite. The data of the two satellites can be used to study many phenomena related to Earth and the environment and follow the changes taking place. This study aims to use Sentinel-1 and Landsat 8 data to monitor the flash floods that occurred in Kuwait in November 2018. Sentinel 1 data are used for direct monitoring after the floods occurred. The Landsat 8 features are utilized for gaining images regarding the weather conditions with an acceptable period after the flash floods.

Consequently, the study raises a question: Can flash floods in Kuwait be modelled through a plan to protect the urban area and infrastructure using RS, GISs, and hydrologic modeling (Youssef and Hegab, 2019; Abdelkarim et al., 2019) and to evaluate the impact of flash flood hazards on the sustainable urban development of Kuwait? Geomorphologically, flood events are when the main changes take place in wadi channels, and one of the major questions is the role of large floods and their relative contribution to, sediment flux, landscape changes and environmental destruction (Hooke, 2016). In this regard, Geomorphology is an effective and important tool in monitoring and tracking these effects on the urban area to find practical solutions for decision-makers and researchers, to achieve environmental adaptation.

\section{STUDY SITE}

With an approximate area of $17,818 \mathrm{~km}^{2}$, the state of Kuwait is in the northwestern corner of the Arabian Gulf, between longitudes $46^{\circ} 30^{\circ}$ and $48^{\circ} 30^{\prime}$ east and latitudes $28^{\circ} 30^{\circ}$ and $30^{\circ} 08^{\prime}$ north. It is bordered by the Arabian Gulf on the east, Iraq on the north and west, and by Saudi Arabia on the south (Fig. 1). Kuwait is an arid region mainly characterized by a dry, long, and very hot summer which runs from the end of March to the end of October. The temperature varies in summer between $30{ }^{\circ} \mathrm{C}$ and $45^{\circ} \mathrm{C}$, reaching $54^{\circ} \mathrm{C}$ during daytime in August. The winter in Kuwait, from early December to middle February, is short, cold, and moderately wet. The temperature in winter varies 
between $7{ }^{\circ} \mathrm{C}$ to $17^{\circ} \mathrm{C}$. The mean total rainfall is less than $125 \mathrm{~mm} /$ year and limited from November to April (A1-Sarawi, 1995; El-Baz and Al-Sarawi, 2000; Kleo et al., 2003; Albanai, 2019).

In general, the surface topography of Kuwait is a rather monotonously flat to gently rolling desert plain (Albanai, 2019), broken by occasional low hills, scarps, valleys of ephemeral streams and shallow but wide inland depressions. The ground slopes generally from about $293 \mathrm{~m}$ above sea level in the extreme southwestern corner of the country towards the lowlands of Iraq and the Khor AlSubiya in the Northeast (Fig. 1). The major topographical features in Kuwait are the Jal-Az-Zor escarpment, Wadi A1-Batin, and the Ahmadi Ridge. It can be concluded that the desert of Kuwait is mostly covered with aeolian sand, which reflects the action of the wind on the loose desert clastic deposits and the aridity of the area (A1-Sarawi, 1995; El-Baz and Al-Sarawi, 2000; Al-Sulamimi and Mukhopadhyay, 2000). Kuwait is characterized as an arid land due to the scarcity of rainwater coupled with hot temperatures of the environment. The rate of evaporation exceeds the rate of precipitation by 30:1 (Al-Sanad and Shaqour, 1990; Al-Rukaibi et al., 2017). However, there are periods during which high-intensity seasonal rainfall far exceeds evaporation, resulting in the formation of water runoff in wadis which in extreme occasions has caused severe flooding (Hassan, 2020). As a result, the flash floods cause intensive damage to the physical infrastructures such as roads, fences, water wells, and oil facilities. Analysis of the hydrological map of the State of Kuwait shows that there are 10 medium-sized drainage basins, with the exception of two large basins located in the north of the country. 


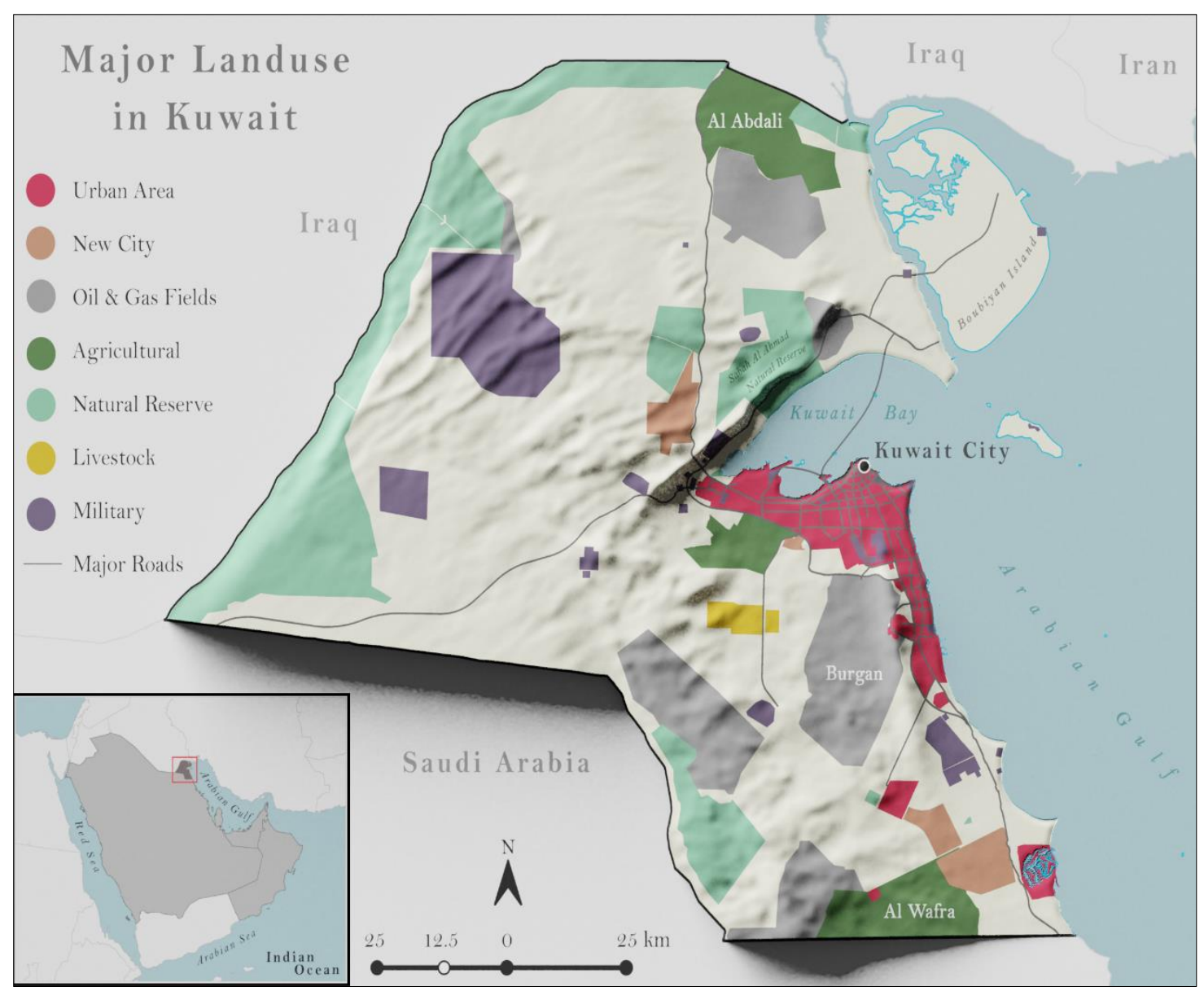

Fig. 1. Study area, showing the major types of land use.

\section{Data and Methodology}

\subsection{Data description}

This study proposes the use of both passive and active RS for flash flood mapping (table.

1). The Sentinel-1 satellite was developed by the ESA (esa.int/) to study and observe the earth and environment. Each Sentinel mission is based on two satellites with similar sensor specification to increase the temporal resolution and spatial coverage. Sentinel-1A and Sentinel-1B satellites were launched into near-polar sun-synchronous orbits in April 2014 and 2016, respectively. They were designed to provide data for seven to twelve years. The satellite data consists of a single C-band of microwave radiation $(5.54 \mathrm{~cm}$ wavelength) in vertical 
polarization. Sentinel-1 has a temporal resolution of 6 days for both satellites. Sentinel-1 data are provided in different levels and products (ESA, 2020). In this study, Sentinel-1A images captured on 25 November 2018 (flood image) and 13 November 2018 (reference image) were used to monitor and detect the flooded areas. The Ground Range Detected (GRD) Level-1 product of Sentinel-1A was used and downloaded freely from the Alaska Satellite Facility (ASF) website (vertex.daac.asf.alaska.edu/). The GRD data are projected to ground range and, as well as complete geo-referenced information being included, they are detected and multilooked. The imaging mode was IW (Interferometric Wide Swath Mode) providing a spatial resolution of $5 * 20$ square meters.

On the other hand, the Landsat 8 data were used to support the radar data of Sentinel-1 in mapping the flooded areas. Landsat 8 is the last satellite of a program started in 1972 to study the geosystem. The satellite was launched in 2013 and carries a multispectral sensor (OLI) that contains bands from early blue to short infrared. Landsat 8 also has a thermal (TIRS) sensor with two bands. The spatial resolution of the OLI and TIRRS sensors are 30 and 100 square meters, respectively. Landsat 8 has a temporal resolution of 16 days (USGS, 2020). Landsat data can be downloaded for free from the US Geological Survey website (earthexplorer.usgs.gov). For this study, Landsat 8 images captured on 24 December 2018 (flood image) and 7 October 2018 (reference image) were used for the mapping of flooded areas.

A DEM represents a 3D view of the Earth's terrain and has significant applications in geomorphology and other fields (Donia, 2020). The ALOS DEM with $12.5 \mathrm{~m}$ resolution, downloaded from the Alaska Satellite Facility (ASF) Distributed Active Archive Center (DAAC) was used to identify and automatically extract drainage networks in the study area. 
Drainage networks and watersheds are identified using DEM and ArcGIS 10.8 software. The watershed data needed for the flood risk study included DEM data, stream network data and surface sediments and land cover data. The stream order of a watershed reflects the ability of a stream to erode and deposit sediment and is therefore linked to soil erosion and flooding. In this study, Strahler's method was used to identify and classify stream type based on tributary numbers (Donia, 2020).

Table 1. Data description.

\begin{tabular}{lllll}
\hline Satellite & Instrument & Path/row & Date & use \\
\hline Sentinel-1 & C-SAR & $174 / 92$ & 25 Nov 2018 & Flood image \\
Sentinel-1 & C-SAR & $174 / 92$ & 13 Nov 2018 & Reference image \\
Landsat-8 & OLI & $166 / 40$ & 24 Dec 2018 & Flood image \\
Landsat-8 & OLI & $166 / 40$ & 7 Oct 2018 & Reference image \\
ALOS PALSAR & DEM 12.5m & & Oct 2014 & Hydrological modeling \\
\hline
\end{tabular}

\subsection{Mapping flash flood (inundated areas)}

Sentinel Application Platform (SNAP) has been used. SNAP is a software package that can be used for processing and analysing all Sentinel missions. The amplitude VV polarization was used to detect the flooded areas, where it gives good results in mapping the flooded areas (Psomiadis, 2016). The images were subset spatially to reduce the processing time and to distribute the colour strip only to the sites to be studied. Following that, the images were radiometrically calibrated to convert the digital numbers to create a standardized scale allowing the comparison of different images. Then, the single product speckle filter has been applied for the images. This filter reduces the complex speckled scattering variance (usual noise) and the estimated speckled scattering coefficient usual noise that occurs in SAR images. After that, the amplitude VV polarization of Sentinel-1 images was converted to a decibel scale to clearly distinguish the flooded 
and non-flooded areas. As for the last processing step, the amplitude VV polarization of the Sentinel-1 image was corrected geometrically using the terrain correction. This type was used for the correction of the topographic difference, which can cause geometric distortions of the image backscatter. As for analysing, the band math tool was used to binarize the images. This was done by setting an empirical value to separate flooded and non-flooded areas (Fig. 2). The image backscatter shows low values for the water and high values for land. These processing and analysing steps have been applied previously in numerous studies (Albanai, 2020; Psomiadis, 2016).

The processing and analysing methodology for Landsat 8 is similar to what was applied for Sentinel-1 images. The images were merged, radiometrically and geometrically calibrated, and corrected. Following that, the Normalized Difference Water Index (NDWI) was applied using the raster calculator in ArcGIS software to determine the flooded areas (Fig. 3). The NDWI is calculated as the ratio between the refracted radiations of the near-infrared $(N I R)$ and the shortwave infrared (SWIR) bands and used to determine the water stress and differences. The NDWI has been used successfully in water differences mapping purposes in several studies (Sagar et al., 2017). The index was calculated using the following formula:

$$
N D W I=\frac{\left(\text { band }_{G}-\text { band }_{N I R}\right)}{\left(\text { band }_{G}+\text { band }_{N I R}\right)} \quad \text { Equation } 1
$$

Where $G$ refers to the green band at $0.53-0.59$ wavelength $(\mu m)$ and NIR refers to the NearInfrared band at $0.85-0.83$ wavelength $(\mu m)$ of Landsat 8 OLI sensor (see fig. 4) 


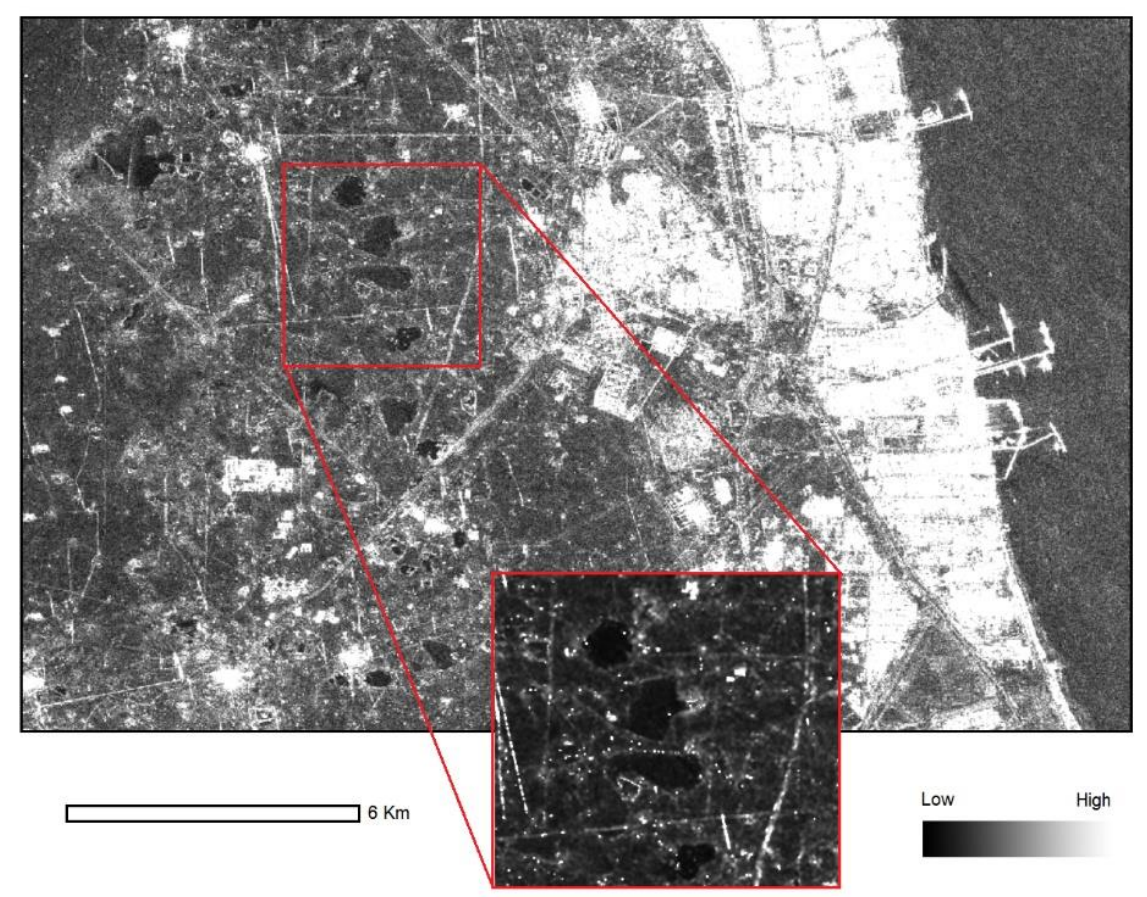

Fig. 2. Example of the extracted flooded lands using a Sentinel-1 image taken on 25 Nov 2018.

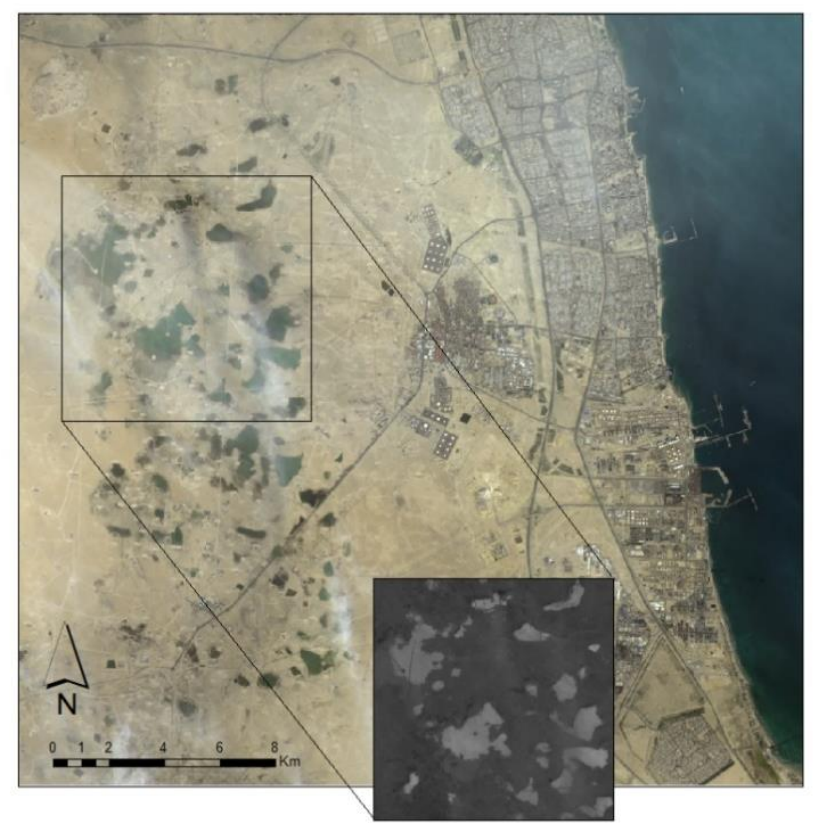

Fig. 3. Example of the extracted flooded lands using a Landsat 8 image taken on 24 Dec 2018. 


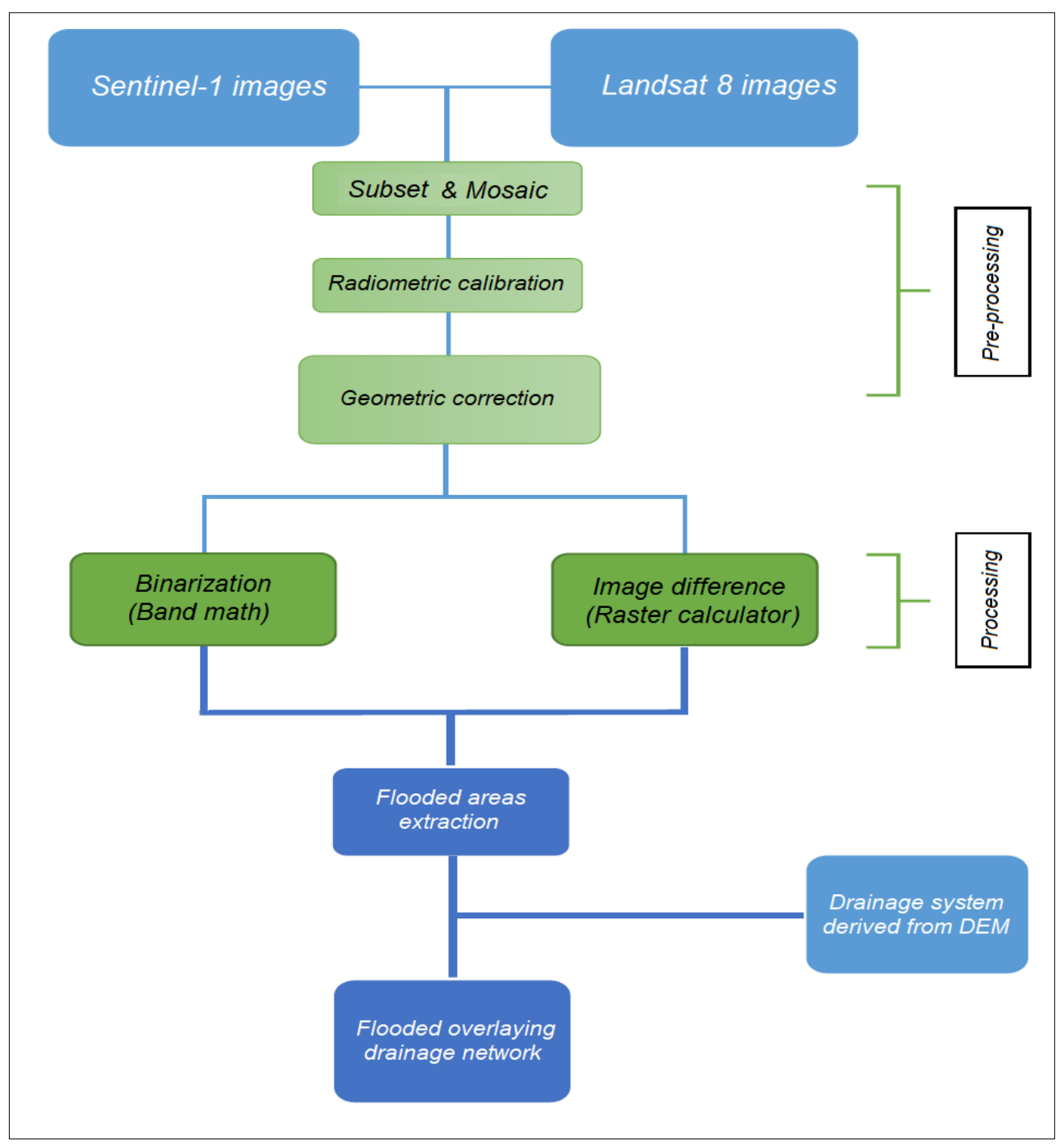

Fig. 4. A summary of the summary of Sentinel-1 and Landsat 8 analysis steps to extract the flooded areas in Kuwait after the November 2018 flash flood.

\subsection{Hydrological analysis}

ArcHydro is a GIS data structure for hydrographic analysis. The ArcHydro application provides the basis for hydrological data modelling (ESRI, 2013). The application is also able to automatically remove artifacts from DEM by conditioning the DEM dataset (Johanna and Jianping, 2019). A Digital elevation model (DEM) is the most important input of the hydrological modeling to get flood hazard maps. The precision of watershed calculation is directly dependent 
on the scale and precision of topographic maps. The difference in the scale of used maps affects the determination of stream orders, and also causes many changes in the ratios of lower order streams (Ismail Elkhrachy, 2015; Dawod et al., 2012). A watershed is an area of land that contributes runoff water to a common point. It is a natural physiographic or ecological unit composed of interrelated parts and functions (Al-Jabari et al., 2009), determined by the topography of the surrounding land. Identifying a watershed is necessary to calculate runoff depth and volume; drainage networks are necessary for water-harvesting activities. In this study, drainage networks and watersheds are identified using a DEM and Arc GIS 10.8 software. It permits the processing and interpretation of enormous spatial and descriptive data and provides outputs in the form of maps and reports (Donia, 2020). The program can also be used to extract basin watersheds, drainage networks, stream ordes, flow, and direction, and other basin characteristics using ArcHydro, part of Arc Toolbox. The software consists of a collection of tools for basin analysis and hydrological applications (O’Callaghan and Mark 1984; ESRI, 2013). Hydrological processing included the following steps (Fill, Flow direction, Flow accumulation, and Watershed).

(Fig. 5 and table 2) shows the results of a GIS analysis of the watershed.

Table 2. The areas of drainage basins $\left(\mathrm{km}^{2}\right)$ and lengths of stream order $(\mathrm{km})$

\begin{tabular}{|c|l|l|l|l|l|l|l|l|l|}
\hline Basins & Basin Area & Stream 1 & Stream 2 & Stream 3 & Stream 4 & Stream 5 & Stream 6 & Total \\
\hline 1 & 798.2382797 & 199.515819 & 122.983454 & 25.1931527 & 0.07130284 & & & 1146.002 \\
\hline 2 & 4654.432483 & 1403.13801 & 544.097075 & 358.086322 & 198.569621 & 25.0531418 & 28.8509579 & 7158.324 \\
\hline 3 & 520.0054533 & 154.469639 & 65.3244086 & 39.4892439 & & & & 779.2887 \\
\hline 4 & 846.7970138 & 144.875582 & 95.8881249 & 21.1981048 & 5.32971304 & & 1114.089 \\
\hline 5 & 4098.857762 & 1281.68232 & 525.608633 & 263.239962 & 228.937007 & 73.7407248 & & 6398.326 \\
\hline 6 & 1292.061849 & 420.943202 & 197.705837 & 99.009694 & 83.2692517 & & & 2092.99 \\
\hline 7 & 2038.741532 & 738.001977 & 307.224401 & 74.4002785 & 84.4918478 & 24.0985463 & & 3242.86 \\
\hline 8 & 2012.628756 & 693.255821 & 326.623483 & 101.479264 & 110.218489 & 27.7978849 & 0.05041872 & 3244.206 \\
\hline 9 & 988.6026494 & 345.108129 & 113.466349 & 105.610494 & 47.0287675 & 5.41707312 & & 1599.816 \\
\hline 10 & 46.24206334 & 6.84967465 & 0.92693688 & & & & & & 54.01867 \\
\hline Total & 17296.60784 & 5387.84018 & 2299.8487 & 1087.70652 & 757.915999 & 156.107371 & 28.9013766 & \\
\hline
\end{tabular}



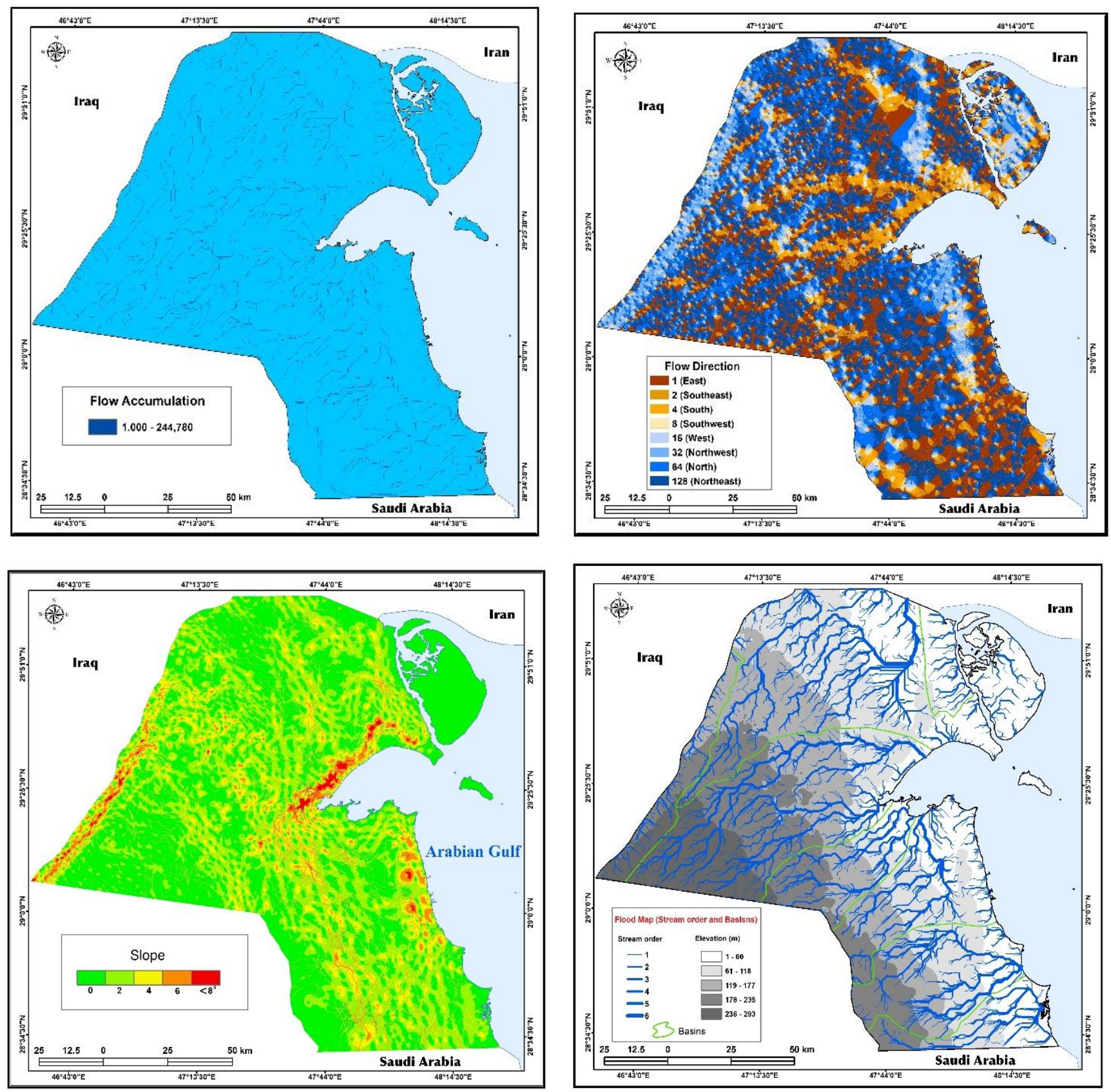

Fig. 5. Layouts of some hydrological processing steps

\section{Results and discussion}

\subsection{Climatic conditions.}

Rain in Kuwait normally falls between October and May, with an average annual rainfall of c $116 \mathrm{~mm}$. The number of rainy days in Kuwait is very limited (29 day/year on average). 
Rainfall events in Kuwait take place with different intensities (Al-Qallaf et al., 2020). In recent decades, the extreme rainfall events show an increase in the occurrence of flash floods, which have caused damage to properties and loss of lives. The highest extreme rainfall event ever recorded since the establishment of meteorological stations in Kuwait was in November 2018. These events caused many flash floods over most of Kuwait (Al-Qallaf et al., 2020). In some years $(1972,1976,1993,1997,2004,2018$ and 2020) the amount exceeded $200 \mathrm{~mm}$. The average amount of rain during November from 2007 to 2017 reached $22.32 \mathrm{~mm}$, while the range reached 51. The highest amount of rain recorded was $59.7 \mathrm{~mm}$ at Umm Almaradim (island) station. As for the lowest value, it reached $8.7 \mathrm{~mm}$, at Umm Qadir station. As for the annual rate, the average annual rate was $81 \mathrm{~mm}$, while the range was $119.7 \mathrm{~mm}$ (the highest value: $129.1 \mathrm{~mm}$ for Umm Almaradim station, the lowest value: 9.4mm for Umm Qadir station) (Table. 3).

As for the total rainfall during 1-16 November 2018, the average amount of rainfall during this period reached $141.03 \mathrm{~mm}$, which is equivalent to about six times the average amount during November (2007-2017), and more than the annual average.. Ahmadi port station recorded the highest value, reaching $285.4 \mathrm{~mm}$, while Abdaly station recorded the lowest value, reaching 43.8mm (range $=241.6)($ Fig. 6) . 
Table 3. Comparison of the amount of rainfall recorded for November 2018 for all stations in Kuwait ( $\mathrm{mm}$ )

\begin{tabular}{|c|c|c|c|}
\hline Station Name & Annual Rate & $\begin{array}{c}\text { November Rate } \\
(2007-2017)\end{array}$ & $\begin{array}{c}\text { Total amount of rain } \\
(1-16 \text { November 2018) }\end{array}$ \\
\hline Abdaly & 106.2 & 28.4 & 43.8 \\
\hline Mitribah & 107.7 & 21.3 & 56.6 \\
\hline Jal aliyah & 83.4 & 18.3 & 120.1 \\
\hline Sabriya & 51.7 & 19.6 & 81.3 \\
\hline Salmy & 73.9 & 19.4 & 101.8 \\
\hline Abraque al habari & 63.1 & 14.4 & 56.3 \\
\hline Rabyah & 86 & 22 & 176 \\
\hline Kuwait Airport & 112 & 20.6 & 173.6 \\
\hline Kuwait City & 83.3 & 18.8 & 236 \\
\hline Ahmadi port & 64.4 & 23.9 & 190.1 \\
\hline Salmiya & 70.4 & 15.3 & 126.7 \\
\hline Jahra & 82.3 & 21.3 & 167.4 \\
\hline Sulaibiya & 78.2 & 15.3 & 226.3 \\
\hline Failaka Island & 95.4 & 25.5 & 176.6 \\
\hline Managish & 76.6 & 14.7 & 147.1 \\
\hline Wafra & 79 & 27.7 & 66.6 \\
\hline Nuwaisib & 86.2 & 29.3 & 171.7 \\
\hline Umm Almaradim & 129.1 & 59.7 & 76.2 \\
\hline Umm qadir & 9.4 & 8.7 & 141.03 \\
\hline Average & 80.96 & 22.32 & 1.7 \\
\hline Source: Kuwait & 1.3 & . \\
\hline
\end{tabular}

Source: Kuwait Meteorological Department, Directorate General of Civil Aviation

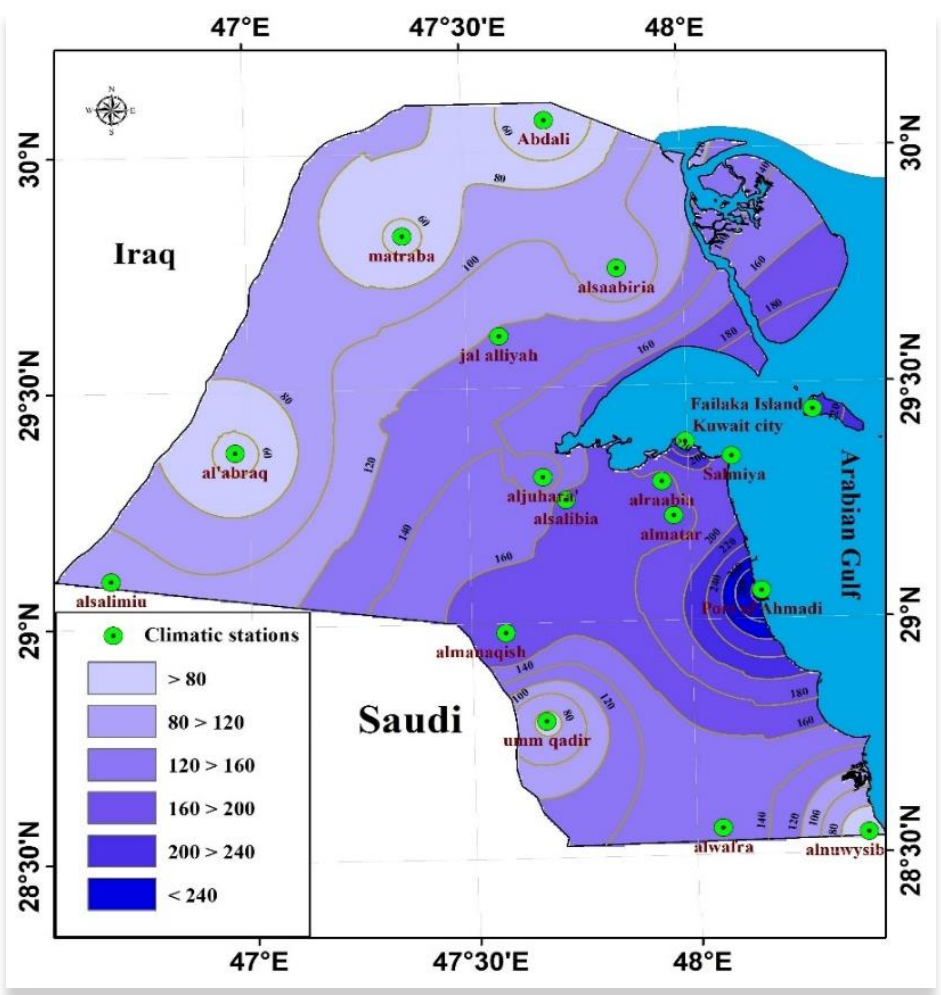

Fig. 6. The amount of rain on the State of Kuwait, November 2018 


\subsection{Hydrological effects on desert areas \& modeling the impact.}

The increase in the amount of rain in desert countries such as Kuwait is a positive aspect, as the increase has several consequences, including: Increased geomorphological activity in surface formation processes, some wadis flow, wildlife boom in the Kuwaiti desert, and recharge of the groundwater aquifers in the areas of Khabrat/Sabkhas (Acworth et al., 2021). Mostly, wadis start to flow clearly and in a flowing stream that starts from the third or fourth orders and ends at the higher orders. Fig. 7 shows areas of water runoff appearing in the network of desert wadis of ranks 3,4,5, and 6. In these higher ranks the flow occurs, and the features of the flow in the valleys are clear. Kuwait's soil which suffers from severe compaction, exacerbates the problem and helps increase the rate of runoff, the most common causes of soil compaction include trampling by livestock and off-road vehicle use on soils with low structural stability, the Gulf War, and the nature of the surface sediments (Al-Dousari et al., 2000; Khalaf et al., 2013). Water harvesting can be used to concentrate and collect water from precipitation and run-off in semi-arid and arid regions. Water harvested in such a relatively small area will not impact the groundwater tables (Rice, 2004). Field work has identified lakes scattered throughout mainland Kuwait (see, Fig. 8). These lakes are attractive areas for road trips and camping travelers throughout the Kuwaiti desert. To calculate runoff the study uses "Runoff equation" (Rashash et al., 2015; AL-Gamdi, 1991; Donia, 2020) which is as follows:

$$
V R=B A * L A R-(e+i) \quad \text { Equation } 2
$$

Where:

$V R=$ Volume of runoff ${ }^{m 3}$

$B A=$ Basin $_{\text {area }} \mathrm{km}^{2}$

$L A R=$ Largest amount of rain fell in one day $(250 \mathrm{~mm} /$ day $)(\mathrm{KMD}, 2020)$.

$e=$ evaporation $(11.6 \mathrm{~mm})(\mathrm{KMD}, 2020)$

$i=$ infiltration 
The results of the application of the previous equation indicate that the amount of runoff is about 4.1 Million $\mathrm{m}^{3}$, noting that the infiltration value is $(0)$ due to the lack of data on it and because the Kuwaiti soil suffers from severe compaction, as mentioned previously. Therefore, it was not considered in the equation.

On the other hand, the results showed the good ability of Landsat 8 to detect flash floods. Monitoring the differences between flooded and non-flooded lands increased after applying the NDWI, which contributes to the monitoring of flooded lands using the green and near-infrared bands. Dense clouds in the first captured image by Landsat 8 after flash floods hindered the partial observation of flooded lands since the OLI sensor of Landsat 8 captures the reflected radiation from the surface, which cannot break through clouds. However, the Radar Satellite Sentinel-1 was relied on to analyze an image that was not affected by dense clouds immediately after the flash flood. Sentinel-1 gave good monitoring accuracy, but the wide variation in the emitted radiations (due to the presence of sporadic urban areas) limited the monitoring of flooded lands. This study proposes the use of passive and active remote sensing as a method for modelling flash floods when data from both become available. Fig. 9 shows the flooded areas after November 2018 flood. Table 4 Shows the descriptive statistics of the flooded areas. 


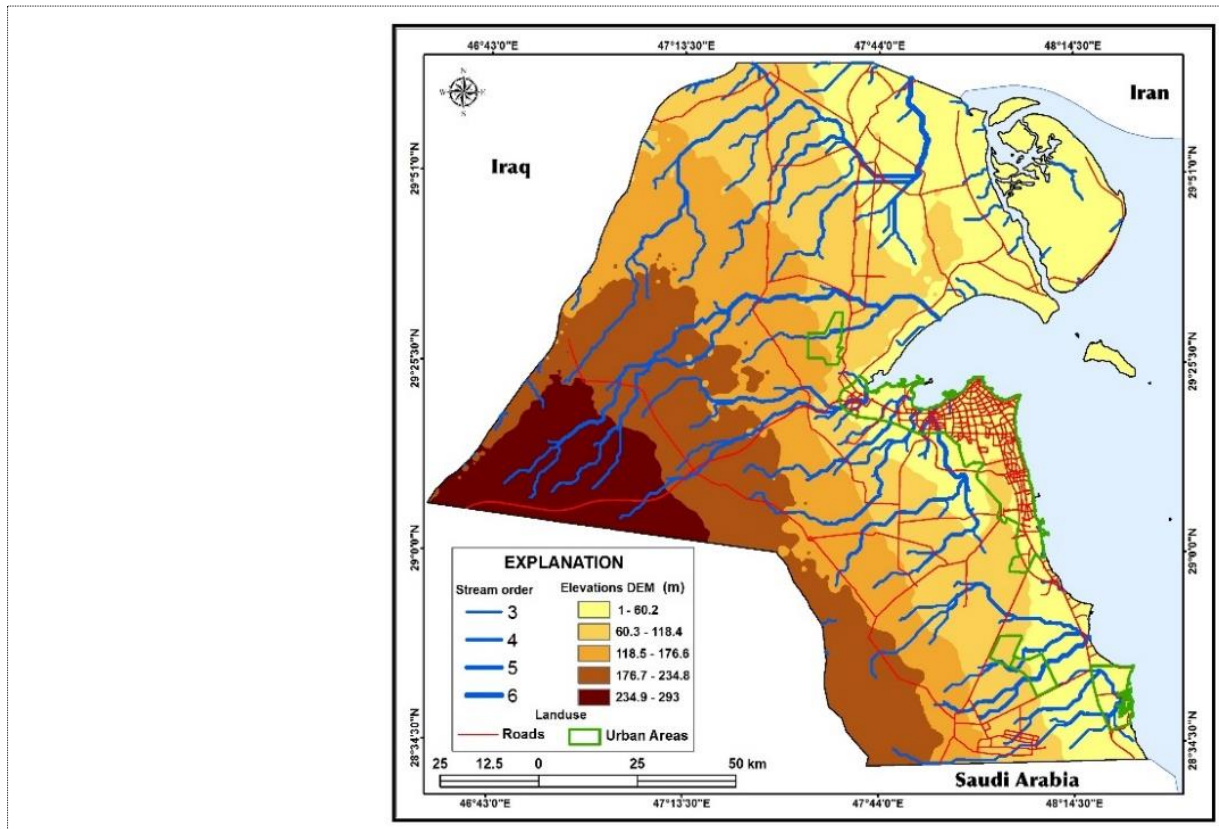

Fig. 7: Runoff areas on the desert and urban area of Kuwait
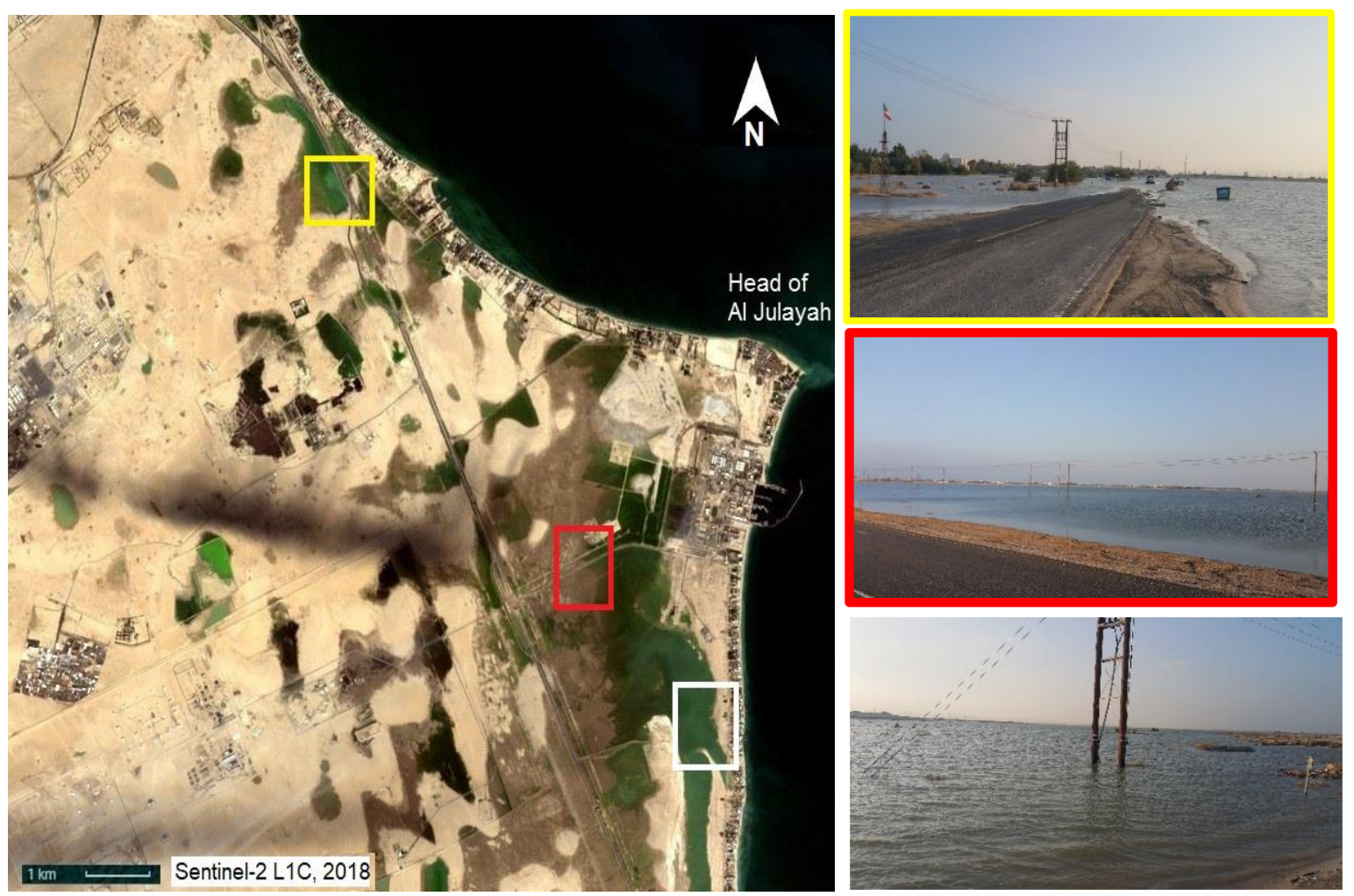

Fig. 8. Rainwater collected in the sabkha of Ras Julai'a area on the south coast of the State of Kuwait. 

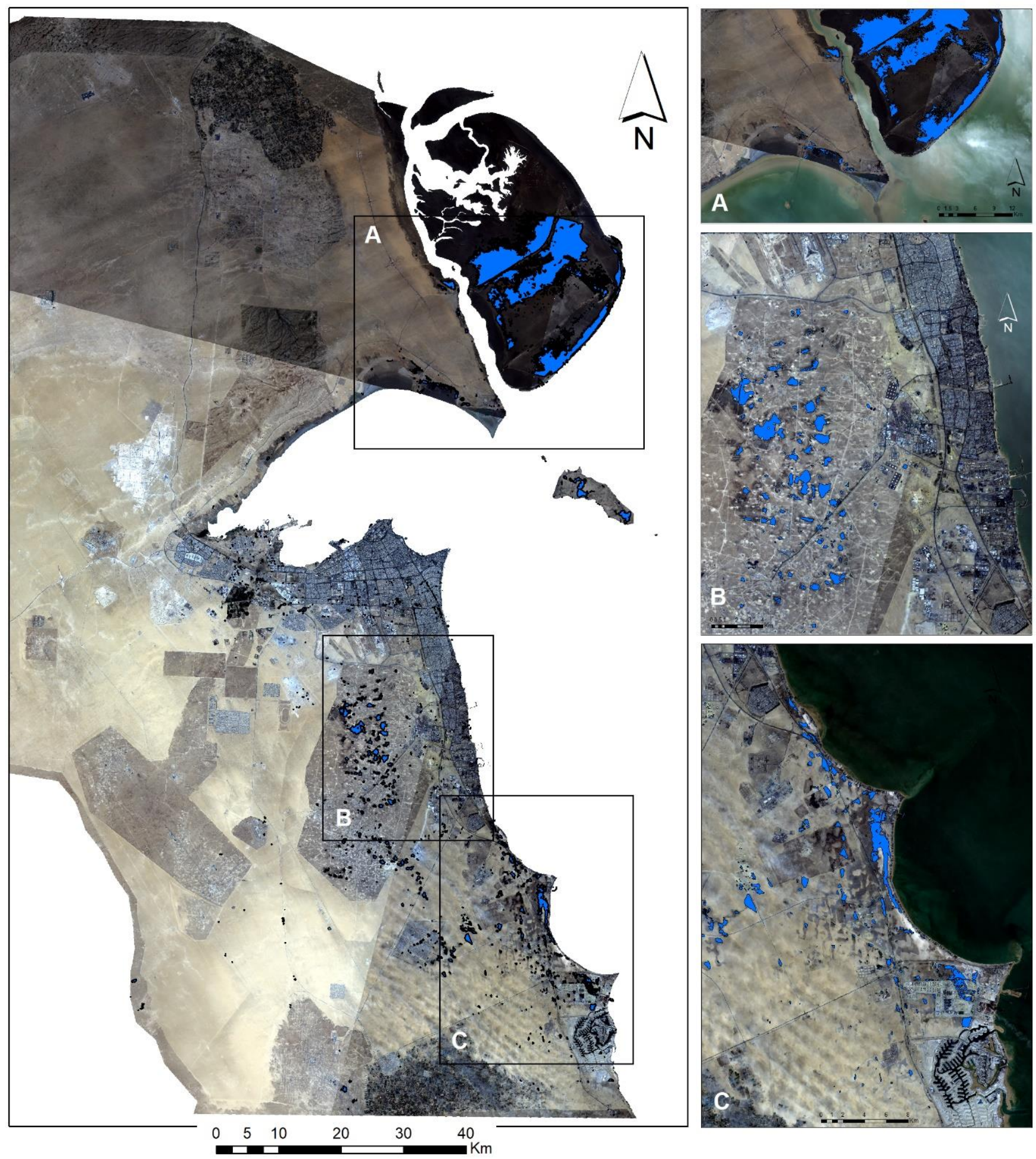

Fig. 9. The flooded lands after the November 2018 rains (a) Bubyan Island and Ras Al-Subiya

(b) the southern part of the urban area and Burgan Oil Field (c) the area extending from Ras Julai'a to Ras Al-Zor. 
Table 4. Descriptive statistics of the flooded lands after November 2018 flash flood.

\begin{tabular}{ll}
\hline Statistics & Value \\
\hline Count & 4243 \\
Minimum & 0.000576 \\
Maximum & 84.089636 \\
Sum & 240.913844 \\
Mean & 0.056779 \\
Standard Deviation & 1.562732 \\
\hline
\end{tabular}

\subsection{The impact on Urban area and infrastructure.}

Flooding caused by storm events becomes a major concern in many parts of the world (A1Zahrani et al., 2017). Doocy et al. (2013) estimated the deaths due to floods worldwide between 1980 and 2009 to be about 539,881 . With more extreme weather patterns predicted in the future, more frequent floods are expected to occur. Although no work could offer a full protection from floods, this does not conflict with the fact that flood modelling gains its importance since it gives a vision of the risk that might threaten lives and properties and gives a clear view for the protection of hydraulic structures which must be constructed (Al-Zahrani et al., 2017). Some researchers have investigated this aspect in several countries (Youssef and Hegab, 2019; Abdelkarim et al., 2019; Dawod et al., 2012). Regarding Kuwait, the flash floods caused a lot of damage to many building structures such as roads, checkpoints, water wells, oil installations and other facilities (Fig. 10). In addition, torrents caused traffic problems, mudslides, and human damage, such as happened on November 1997 and November 2018. The study used two methods to monitor the impact of floods on the urban area in Kuwait, Google Map Traffic (Fig. 11), and field visits to easy-to-reach areas, and imaging with a drone, to monitor hard-to-reach areas. 

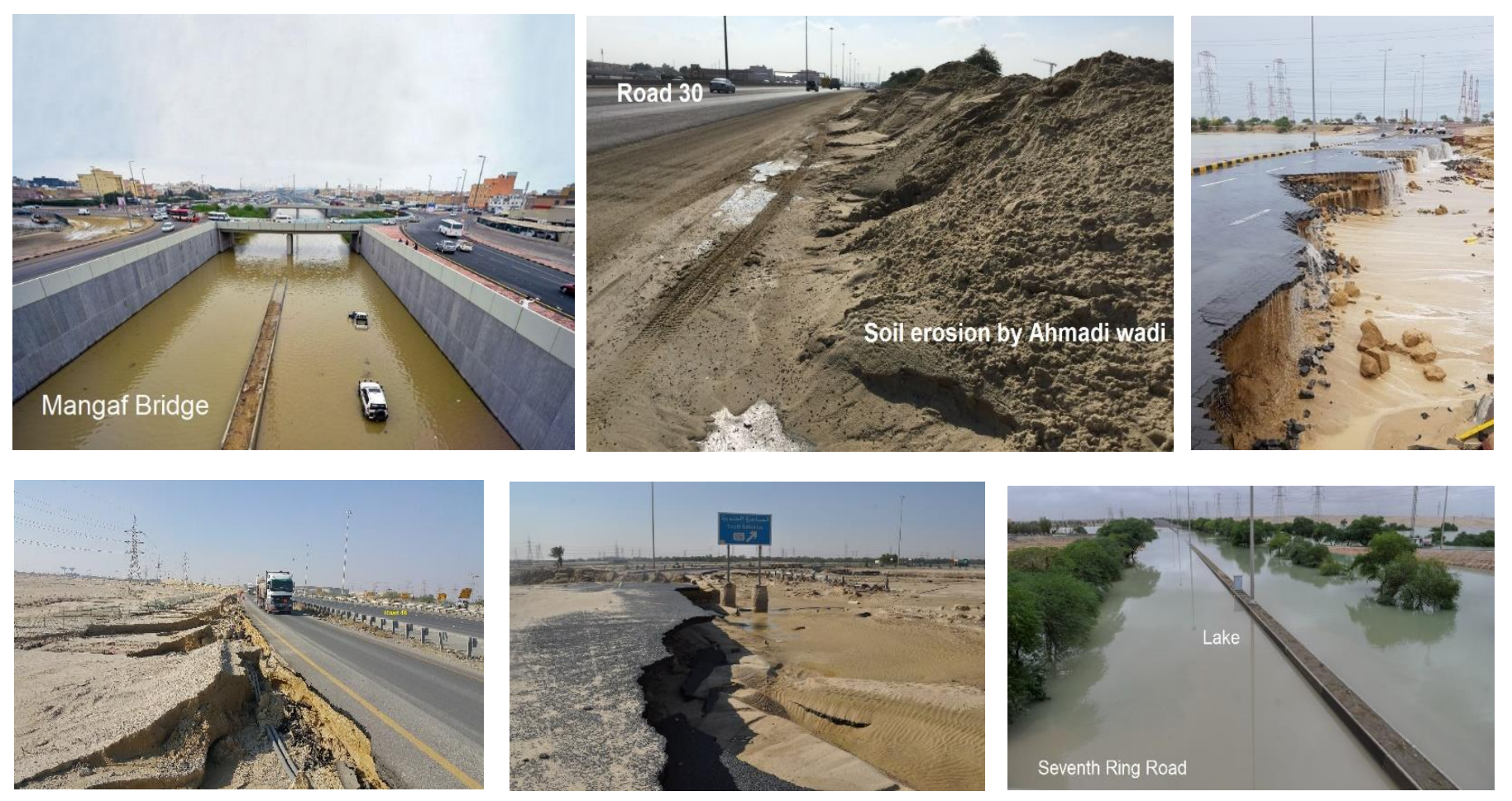

Fig. 10. Roads and property damage due to the flash flood in 2018

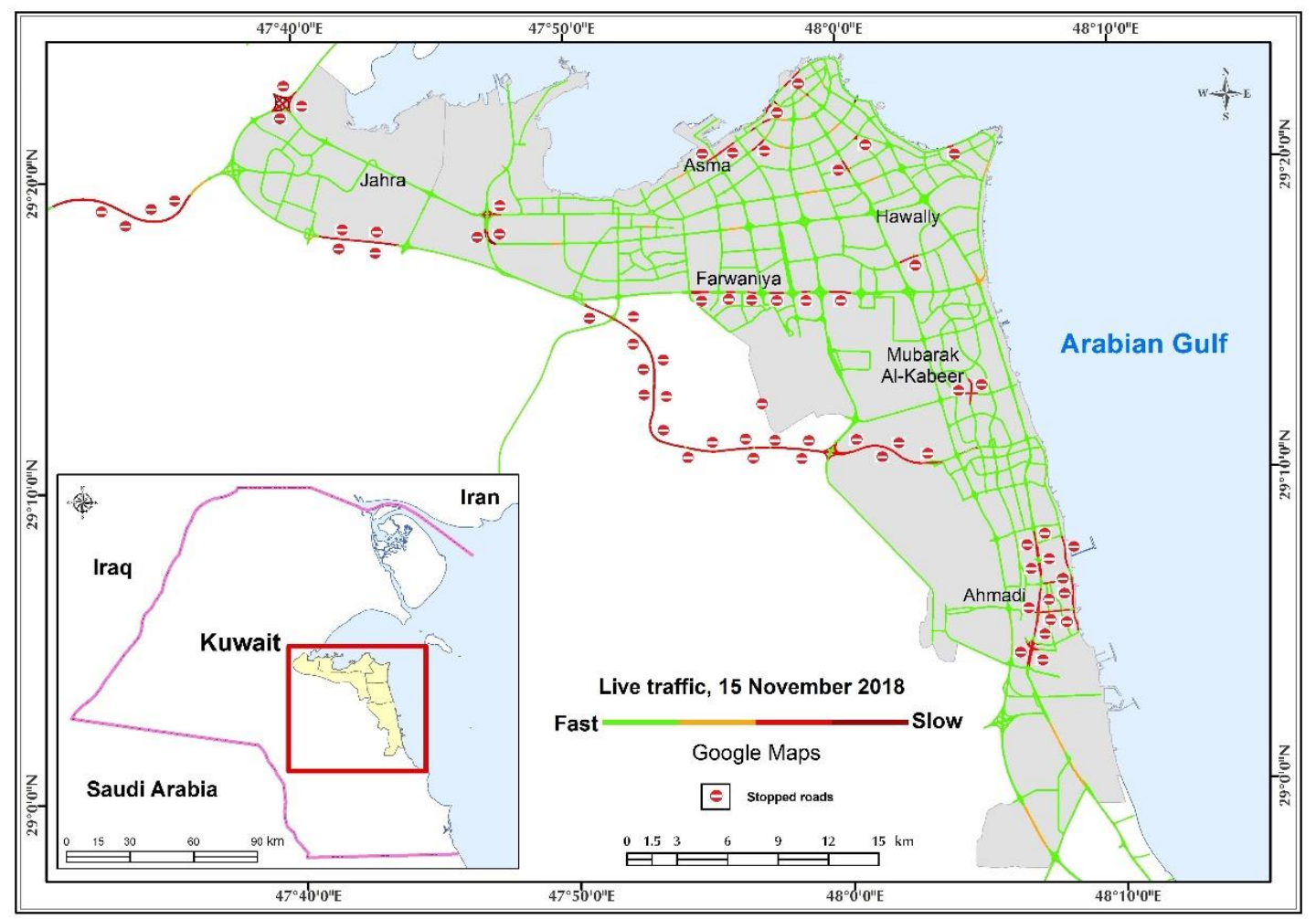

Fig. 11: Roads stopped/closed after a rainstorm, Source: Live traffic, Google maps, 15 November 2018 


\subsection{Flood water management in Kuwait.}

There are many disruptive effects of flooding on human settlements and economic activities. However, flooding can bring benefits, such as making the soil more fertile and providing nutrients in which it is deficient. Periodic flooding was essential to the well-being of ancient communities along the Tigris-Euphrates Rivers, the Nile River, the Indus River, the Ganges, and the Yellow River (Zoran and Michael., 2012). Flash floods are a potential source of freshwater. However, flash floods are seldom considered as a source of water due to the unavailability of management resources (Munir et al., 2021). The State of Kuwait suffers from a severe shortage of water resources, as it relies on the desalination of seawater as a source of drinking water, which is a very costly source. In this case, rainstorm water is a very important source of freshwater. However, runoff in the arid zone commonly occurs as a result of of exceptional storms. Under such circumstances, monitoring infrastructure, if present, often fails or is destroyed, often leaving only estimates of runoff occurrence, rainfall distribution and general assumptions concerning groundwater recharge (Acworth et al., 2021). After the rainstorm that hit the whole of the State of Kuwait in November 2018, the state embarked on developing a plan to protect the urban area and the infrastructure. Although the steps are weak and the plan is incomplete, there are two good places in which the state has constructed a dam and a reservoir to store rainstorm water (see figure 12, A and B). Steps to protect all parts of the country need to be completed. Fig. 12 represents an initial attempt to identify the most appropriate places to store rainstorm water based on the stream order. There are 22 areas suitable for storing rainwater for use in agriculture or drinking water. Although the method followed by the state in fig. $12 \mathrm{~A}$ and $\mathrm{B}$ is good, it would have been better also to cover the storage pits, so that water is not lost and evaporated without benefiting from it. Field 
measurements of the volumes of the two lakes indicate in (fig. 12), about 650,000 cubic meters can be stored in each storage pit, and thus if the state completes the dams and reservoirs plan proposed by the current study, the state will be able to store about 15 million cubic meters. It is a good policy to plant green belts around cities to protect them from dust storms and flash floods, as plants contribute directly to stabilizing and protecting the soil, and they also contribute to moderating the temperature in the desert climate that the State of Kuwait suffers from.
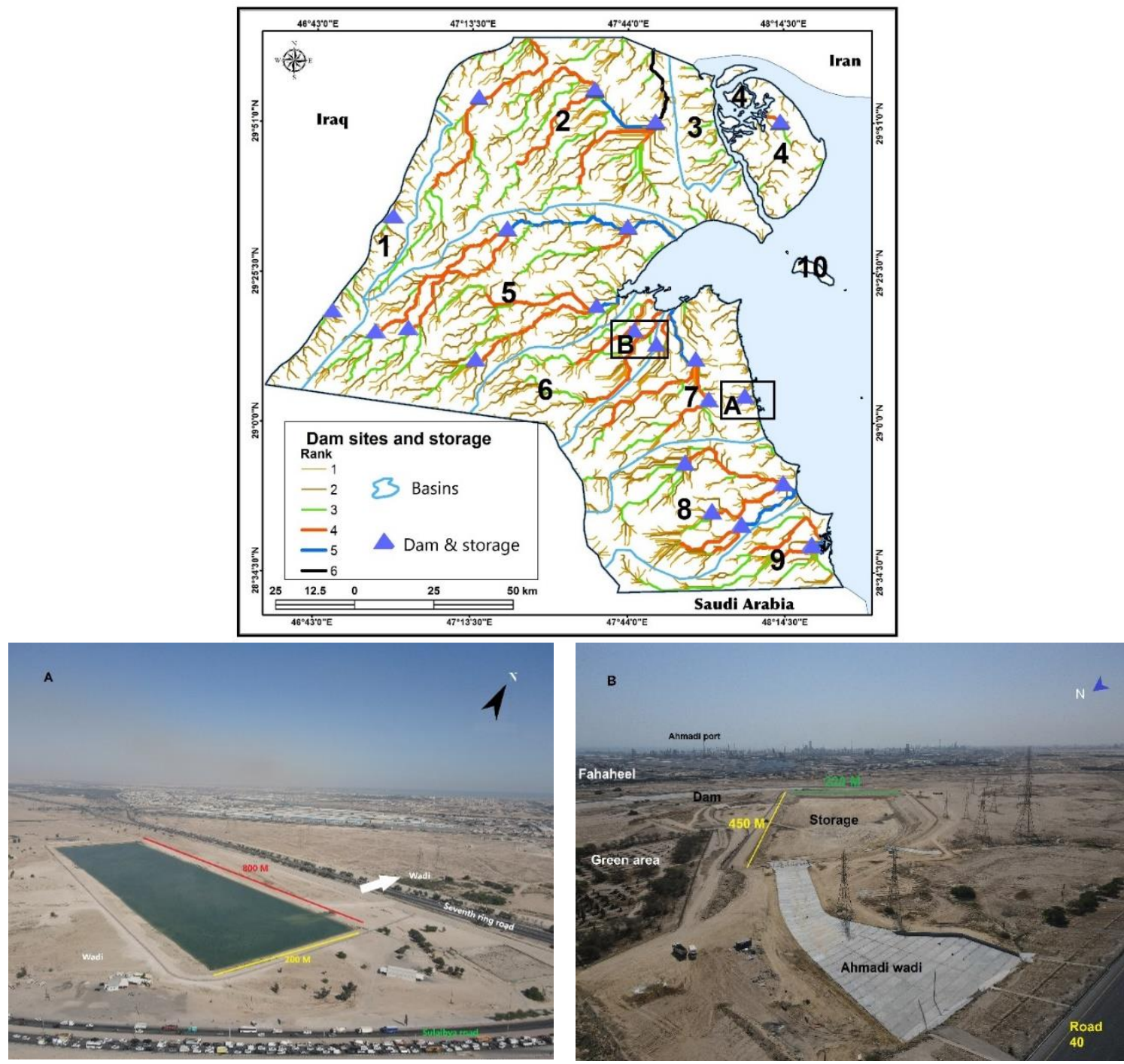

Fig. 12. Suggested locations for storing rainstorm water. 
Protecting new cities from the risk of flooding is extremely important. Geomorphology and hydrology provide practical solutions that help mitigate floods (Hassan et al., 2021). After the rainstorm that hit Kuwait on November 14 and 15, 2018, about $140 \mathrm{~mm}$ fell on the city of Sabah Al-Ahmad, and as a result the city declared a natural disaster area. This study proposes a combination of damsldykes and water storage as in figure 13, where the most appropriate sites were determined based on the ranks of wadis and the digital elevation model. The example explained in figure 13 represents a case study that can be applied to new cities in Kuwait that will be announced in the future, such as Al-Mutlaa City in northern Kuwait and South Sabah Al-Ahmad City. This last city will face very big problems in the event of a flash flood, as it is crossed in the middle by wadis of the sixth rank, and if no consideration is taken to protect the city from storms rain, the situation will be very dangerous. 


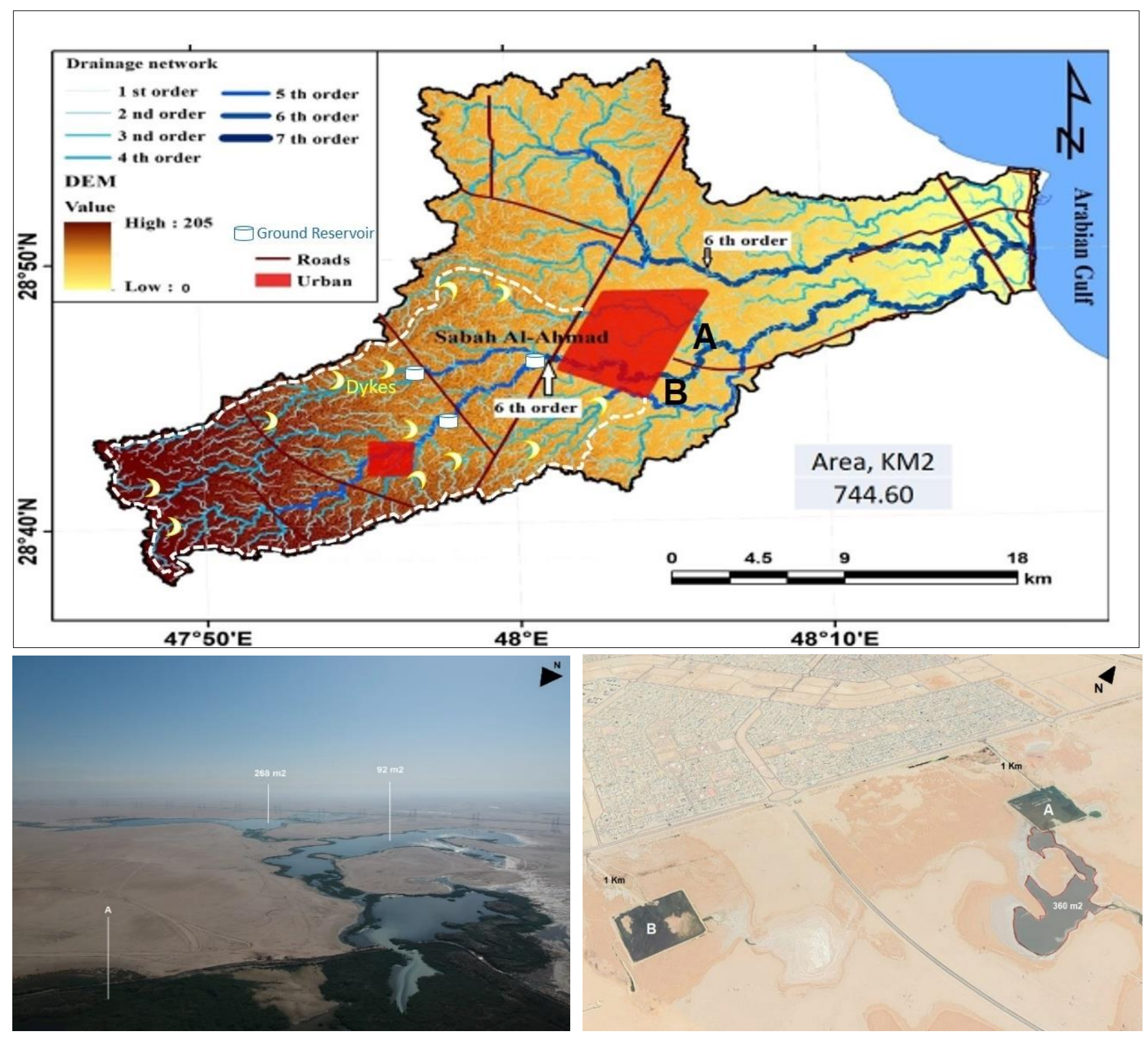

Fig 13. A preliminary proposal to reduce the severity of torrents in the city of Sabah Al-Ahmad, based on dams/dykes in the wadis and underground reservoirs. Lower left image shows lakes formed near Sabah Al-Ahmad city. A and B represent the storage areas used to contain wastewater (source: arial photography by drone, and Google Earth image, 14 December 2020). The protection plan of Sabah Al-Ahmad prepared by prof. Rafaat Misak.

\section{Conclusion.}

The State of Kuwait suffers from occasional flash floods associated with large rainfall events, and exacerbated by the nature of the desert surface over large areas. Although these floods have certain positive advantages (e.g. groundwater recharge, stimulation of vegetation growth), they can 
damage various types of infrastructure including road and cities. In this paper, it was shown how a combination of GIS and RS could be used to map areas prone to the effects of flash floods, and to identify areas where flood water could be stored to augment freshwater resources. The floods of November 2018 were studied, and the two RS platforms employed were Landsat 8 and Senitnel1. It is recommended that this methodology be employed further and used to identify areas that may be at particular risk, such as the proposed South Sabah Al-Ahmad City and Al-Mutla'a City.

\begin{tabular}{l|l} 
Funding: & There is no funding.
\end{tabular}

Competing interests $\quad$ The authors declare no competing interests.

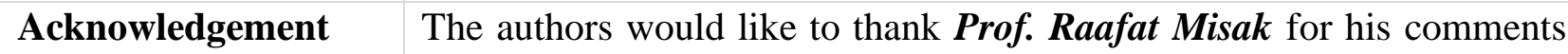
that enriched and improved the work. The authors thank Dr. Abdullatif Alyaqout from Geography department, Kuwait University for preparing Figure 1. Thanks also go to Mr. Mahmoud Fayad for helping us draw some maps.

\section{REFERENCES}

1. Abdelkarim, A., Gaber, A., Youssef, A., Pradhan, B. (2019). Flood hazard assessment of the urban area of Tabuk City, Kingdom of Saudi Arabia by integrating spatial-based hydrologic and hydrodynamic modeling. Sensors, 19 (5), 1024; https://doi.org/10.3390/s19051024

2. Acworth, R.I., Rau, G.C., Cuthbert, M.O. et al., (2021). Runoff and focused groundwaterrecharge response to flooding rains in the arid zone of Australia. Hydrogeol J., 29, 737-764. https://doi.org/10.1007/s10040-020-02284-x.

3. Ahmad, S., Simonovic, S. (2011). A three-dimensional fuzzy methodology for flood risk analysis. J. Flood, Risk Manag, 4, 53-74. https://doi.org/10.1111/j.1753-318X.2011.01090.x 
4. Albanai, J.. (2021). Mapping Kuwait bathymetry using passive multispectral remote sensing. Kuwait Journal of Science. In printing.

5. Albanai, J. . (2020). Sea level rise projections for Failaka Island in the State of Kuwait. Transactions on Maritime Science, 9, 236-247. 10.7225/toms.v09.n02.008.

6. Albanai, J.. (2019). A GIS Science Simulation for the Expected Sea Level Rise Scenarios on Failaka Island in the State of Kuwait.

7. Al-Dousari, A. Misak, R., Shahid, S.. (2000). Soil compaction and sealing in AL-Salmi area, Western Kuwait. Land Degradation \& Development 11. 401-418. 10.1002/1099-145X (200009/10)11:53.0.CO;2-4.

8. AL-Gamdi, S. (1991). Estimating runoff curve numbers of the Soil Conservation Service in arid and semi-arid environments using remotely sensed data. A dissertation Submitted to the University of Utah, USA.

9. Al-Jabari, S., Sharkh, A. M., Al-Mimi, Z. (2009). Estimation of runoff for agricultural watershed using SCS curve number and GIS. In Thirteenth International Water Technology Conference, IWTC 13 Hurghada, Egypt.

10. Al-Rukaibi, D., Waleed, A., Rana, F and Mohammed H (2017). Site Suitability Index (SSI) model to delineate and assess suitability of rainwater runoff basins in Jal Alzor Heights, Kuwait. Jordan Journal of Civil Engineering, 11, ( 3), pp386-397.

11. Al-Qallaf, H., Aliewi, A.,Abdulhadi, A. (2020) Assessment of the effect of extreme rainfall events on temporal rainfall variability in Kuwait. Arab J. Geosci., 13, 1129.https://doi.org/10.1007/s12517-020-06086-z.

12. Al-Sanad, H., Shaqour, F (1990). Effect of groundwater level changes on the engineering properties of desert sands in Kuwait. Research Unit No. EV030, Kuwait University, Kuwait. 
13. A1-Sarawi, M. (1995). Surface Geomorphology of Kuwait, GeoJournal, 35 (4), 493-503.

14. Al-Sulamimi, J., Mukhopadhyay, A. (2000). An overview of the surface and near surface geology, geomorphology, and natural resources of Kuwait. Earth-Science Reviews, 50, (3-4), 227-267.

15. Dawod, G. M., Mirza, M. N., Al-Ghamdi, K. A. (2012). GIS-based estimation of flood hazard impacts on road network in Makkah city, Saudi Arabia. Environmental Earth Sciences, 67, 2205_2215. Available from, https://doi.org/10.1007/s12665-012-1660-9.

16. Donia, N. (2020). Environmental monitoring and evaluation of flash floods using remotesensing and GIS techniques. In: Negm A. (ed) Flash Floods in Egypt. Advances in Science, Technology \& Innovation (IEREK Interdisciplinary Series for Sustainable Development). Springer, Cham. https://doi.org/10.1007/978-3-030-29635-3_8

17. Doocy, S., Daniels, A., Murray, S., Kirsch, T.D. (2013). The human impact of floods: a historical review of events 1980-2009 and systematic literature review. PLoS Curr. 5. doi: 10.1371/currents.dis.f4deb457904936b07c09daa98ee8171a.

18. ESA. (2021). Sentinel-1. Retrieved 23 March 2021, from sentinel.esa.int/web/sentinel/missions/sentinel-1.

19.ESRI, 2013. Arc Hydro: GIS for Water Resources. ESRI, Redlands, California.

20. El-Baz, F.; Al-Sarawi, M. (2000). Atlas of the State of Kuwait from Satellite Images; Kuwait Foundation for the Advancement of Sciences: Kuwait.

21. Essel, B. (2017). The application of GIS in mapping of flood hazard areas and assessing of risk in Kumasi, Ghana, J. Energy Nat. Resour. Manag. JENRM, 3, 97-103. 
22. Hassan, A.; Alfaraj, M.; Fayad, M.; Allen, C.D. (2021). Optimizing Site Selection of New Cities in the Desert Using Environmental Geomorphology and GIS: A case study of Kuwait. Preprints 2021, 2021030574 (doi: 10.20944/preprints202103.0574.v1).

23. Hooke, J.M. (2016): Geomorphological impacts of an extreme flood in SE Spain, Geomorphology, 263, 19-38. https://doi.org/10.1016/j.geomorph.2016.03.021

24. Elkhrachy, I. (2015). Flash flood hazard mapping using satellite images and GIS Tools: A case study of Najran City, Kingdom of Saudi Arabia (KSA).Egyptian Journal of Remote Sensing and Space Science, 18, (2), 261-278, https://doi.org/10.1016/j.ejrs.2015.06.007

25. Ismail E., Quoc B., Romulus C., Meriame M., Khali U., Himan S., Nguyen T., (2021). Sentinel1 remote sensing data and Hydrologic Engineering Centres River Analysis System twodimensional integration for flash flood detection and modelling in New Cairo City, Egypt, 2021. Journal of Flood Risk Management published by Chartered Institution of Water and Environmental Management and John Wiley \& Sons Ltd. https://doi.org/10.1111/jfr3.12692.

26. Niipele, J.,Chen, J. (2019). The usefulness of alos-palsar dem data for drainage extraction in semi-arid environments in the Iishana sub-basin, Journal of Hydrology: Regional Studies, 21, 57-67, https://doi.org/10.1016/j.ejrh.2018.11.003

27. Mishra, K. Sinha, R. . (2020) Flood risk assessment in the Kosi megafan using multi-criteria decision analysis: A hydro-geomorphic approach, Geomorphology, 350, 106861, https://doi.org/10.1016/j.geomorph.2019.106861.

28. Khalaf F.I., Al-Awadhi J., Misak R.F. (2013) Land-Use Planning for Controlling Land Degradation in Kuwait. In: Shahid S., Taha F., Abdelfattah M. (eds) Developments in Soil Classification, Land Use Planning and Policy Implications. Springer, Dordrecht. https://doi.org/10.1007/978-94-007-5332-7_39 
29. Kleo, A., Abo Al-Enein, H., Al-Husseini, S., Taibaa, A., Al-Sheikh, M (2003). Selected Studies in the Geomorphology of Kuwaiti Lands, Kuwait Research and Studies Center, Kuwait.

30. Kuwait Institute for Scientific Research (KISR). (2000): Natural resources and environmental features in the State of Kuwait”, Technical Report, KISR, Kuwait.

31. KMD, Kuwait Metrological Department (2020): https://www.met.gov.kw/Climate/climate_hist.php?lang=arb

32.Lowry, R. T., Langham, E. J., Murdy, N., (1981) A preliminary analysis of SAR mapping of Manitoba flood" Proc. Satellite Hydrology, Fifth Anniversary William T. Pecora, Memorial Symposium on Remote Sensing American, Water Resource Association Technical Publication, 81(1), 316-323.

33. Mason, D., Bates, P., Dall, Amico (2009). Calibration of uncertain flood inundation models using remotely sensed water levels. J. Hydrol., 368, 224-236. https://doi.org/10.1016/j.jhydrol.2009.02.034.

34. Misak, R., Hamdy, G., Al-dousari, A. (2012): Managing natural hazards in HIMA the case of Kuwait, International Workshop: Towards an Implementation Strategy for the HIMA Governance Systems, KISR, Kuwait.

35. Misak, Raafat (2015): GIS Representation of Flash Floods and GIS Representation of Sea Level Rise, Crisis Decision Support Program, Environment and Life Sciences Research Center, KISR, Kuwait.

36. Munir, B.A.; Ahmad, S.R.; Rehan, R. (2021). Torrential flood water management: rainwater harvesting through relation based dam suitability analysis and quantification of erosion potential. ISPRS Int. J. Geo-Inf. 10, 27. https://doi.org/10.3390/ijgi10010027 
37. Al-Zahrani, M., Al-Areeq, A., Hatim O. (2017) Estimating urban flooding potential near the outlet of an arid catchment in Saudi Arabia, Geomatics, Natural Hazards and Risk, 8(2), 672688, DOI: $10.1080 / 19475705.2016 .1255668$.

38. O’ Callaghan, J. F., Mark, D. M. (1984). The extraction of drainage networks from digital elevation data. In Computer Vision, Graphics And Image Processing 28, 323-344.

39. Parcharidis I., Lagios E., Psomiadis E., 2001. Multitemporal hazard assessment in a high flash flood risk area using RS/GIS techniques: The case study of Hymittos Mt. (Athens). 9th International Congress of the Geological Society of Greece, 5, 2055-2062.

40. Portugués-Mollá, I., Bonache-Felici, X., Mateu-Bellés, J., Marco-Segura, B. (2016): A GISbased model for the analysis of an urban flash flood and its hydrogeomorphic response, the Valencia event of 1957. Journal of Hydrology, 541, 582-596. https://doi.org/10.1016/j.jhydrol.2016.05.048.

41. Psomiadis E., Parcharidis I., Poulos S., Migiros G.,(2004). Short period change detection of Sperchios lower delta area using space radar images. Proc. of 10th International Congress of the Geological Society of Greece, 36, 919-927.

42. Psomiadis, E.. (2016). Flash flood area mapping utilising SENTINEL-1 radar data. $10.1117 / 12.2241055$

43. Rashash Ali, A., Mohamed, E. S., Belal, A., El Shirbeny, M. (2015). GIS spatial model based for DAM reservoir on dry Wadis ACRS 2015. In 36th Asian Conference on Remote Sensing: Fostering Resilient Growth in Asia.

44. Rice, W.E. (2004). Desert water harvesting to benefit wildlife: a simple, cheap, and durable sub-surface water harvester for remote locations. Environ Monit Assess 99, 251-257. https://doi.org/10.1007/s10661-004-4030-6. 
45.Sagar, S., Roberts, D., Bala, B., Lymburner, L. (2017). Remote Sensing of Environment Extracting the intertidal extent and topography of the Australian coastline from a 28 year time series of Landsat observations. Remote Sensing of Environment, 195, 153-169. https://doi.org/10.1016/j.rse.2017.04.009

46. Sanyal, J., Lu, X.X., (2004). Application of remote sensing in flood management with special reference to Monsoon Asia: A Review. Natural Hazards 33, 283-301 (2004).

47. System of environmental monitoring information (EMISK), Various maps :surface sediments, geology, Geomorphology unites, and Land use, https://epa.org.kw/en-us/eMISK

48. USGS. (2020). Landsat Mission. Retrieved March 24, 2021, from usgs.gov/landresources/nli/landsat

49. Wang, Y., Hess, L. L., Filoso, S., Melack, J. M., (1995). Understanding the radar backscattering from flooded and non-flooded Amazonian forests: Results from canopy backscatter modeling. Remote Sensing of Environment, 54, 324-332.

50. Youssef, A., Biswajeet, P., Abdallah, H (2011): Flash flood risk estimation along the St. Katherine road, southern Sinai, Egypt using GIS based morphometry and satellite imagery, Environ Earth Sci, 62:611-623, DOI 10.1007/s12665-010-0551-1.

51. Youssef, A., Mahmoud, H (2019) Flood-hazard assessment modeling using multicriteria analysis and GIS: a case study Ras Gharib Area, Egypt. chapter 10 in book "Spatial Modeling in GIS and R for Earth and Environmental Sciences”, Editor(s): Hamid Pourghasemi, Candan Gokceoglu, Elsevier, Pages 229-257. DOI: https://doi.org/10.1016/B978-0-12-8152263.00010-7 
52. Youssef, A., Pradhan, B., Hassan, A. (2011): Flash flood risk estimation along the St. Katherine road, southern Sinai, Egypt using GIS based morphometry and satellite imagery. Environ Earth Sci 62, 611-623. https://doi.org/10.1007/s12665-010-0551-1

53. Vojinović, Z., Abbott, M. (2012): Flood Risk and Social Justice: From Quantitative to Qualitative $\quad$ Flood $\quad$ Risk Assessment and Mitigation. DOI: https://doi.org/10.2166/9781780400822 